Article

\title{
Enhanced Biogas Production of Cassava Wastewater Using Zeolite and Biochar Additives and Manure Co-Digestion
}

\author{
Chibueze G. Achi ${ }^{1,2}$, Amro Hassanein ${ }^{1}$ and Stephanie Lansing ${ }^{1, *(\mathbb{D})}$ \\ 1 Department of Environmental Science \& Technology, University of Maryland, College Park, MD 20742, USA; \\ achicgjr@gmail.com (C.G.A.); ahassane@umd.edu (A.H.) \\ 2 Department of Civil Engineering, University of Ibadan, Ibadan 200284, Nigeria \\ * Correspondence: slansing@umd.edu
}

Received: 30 November 2019; Accepted: 14 January 2020; Published: 19 January 2020

check for updates

\begin{abstract}
Currently, there are challenges with proper disposal of cassava processing wastewater, and a need for sustainable energy in the cassava industry. This study investigated the impact of co-digestion of cassava wastewater (CW) with livestock manure (poultry litter (PL) and dairy manure (DM)), and porous adsorbents (biochar (B-Char) and zeolite (ZEO)) on energy production and treatment efficiency. Batch anaerobic digestion experiments were conducted, with 16 treatments of $\mathrm{CW}$ combined with manure and/or porous adsorbents using triplicate reactors for 48 days. The results showed that $\mathrm{CW}$ combined with ZEO ( $3 \mathrm{~g} / \mathrm{g}$ total solids (TS)) produced the highest cumulative $\mathrm{CH}_{4}(653 \mathrm{~mL}$ $\mathrm{CH}_{4} / \mathrm{g}$ VS), while $\mathrm{CW}: \mathrm{PL}(1: 1)$ produced the most $\mathrm{CH}_{4}$ on a mass basis $\left(17.9 \mathrm{~mL} \mathrm{CH}_{4} / \mathrm{g}\right.$ substrate). The largest reduction in lag phase was observed in the mixture containing CW (1:1), PL (1:1), and B-Char ( $3 \mathrm{~g} / \mathrm{g} \mathrm{TS}$ ), yielding $400 \mathrm{~mL} \mathrm{CH}_{4} / \mathrm{g}$ volatile solids (VS) after 15 days of digestion, which was $84.8 \%$ of the total cumulative $\mathrm{CH}_{4}$ from the 48 -day trial. Co-digesting $\mathrm{CW}$ with $\mathrm{ZEO}$, B-Char, or PL provided the necessary buffer needed for digestion of $\mathrm{CW}$, which improved the process stability and resulted in a significant reduction in chemical oxygen demand (COD). Co-digestion could provide a sustainable strategy for treating and valorizing CW. Scale-up calculations showed that a CW input of 1000-2000 L/d co-digested with PL (1:1) could produce $9403 \mathrm{~m}^{3} \mathrm{CH}_{4} / \mathrm{yr}$ using a $50 \mathrm{~m}^{3}$ digester, equivalent to $373,327 \mathrm{MJ} / \mathrm{yr}$ or 24.9 tons of firewood/year. This system would have a profit of $\$ 5642 / \mathrm{yr}$ and a $\$ 47,805$ net present value.
\end{abstract}

Keywords: methane; fermentation; dairy; poultry; absorbent

\section{Introduction}

Eutrophication and organic pollution resulting from poor management of wastes from food processing industries, such as cassava processing industries, is a major problem in many developing countries [1,2]. Cassava (Manihot esculenta) is a starch-containing root crop of global importance that can be processed into food, feed, and other non-food products [3]. The cassava processing industry is a key industry in many developing countries, especially in Africa, but also in parts of Latin America and Asia. In 2017, the African region contributed 55\% of the global production of cassava, equivalent to 121 million tons, with $25-37 \%$ of the crop discarded as waste in the form of peels and pulp $[4,5]$, and approximately $60,000 \mathrm{~L}$ of effluent generated from each ton of cassava tubers processed $[3,6]$. Meanwhile, more than $70 \%$ of cassava production in sub-tropical and tropical regions of the world is conducted by small and medium-scale farmers $[7,8]$. These small and medium-scale cassava industries lack the capacity to treat the large waste streams resulting from daily cassava roots processing, which can lead to environmental degradation and pollution of nearby water bodies [9]. Additionally, farmers 
often depend solely on firewood as a source of energy to process cassava, which has associated negative environmental impacts.

Bioenergy from organic wastes materials through anaerobic digestion (AD) can be used to produce renewable energy from this organic-rich wastewater, while reducing the concentrations of organic pollutants [10]. Cassava wastewater (CW) has a high organic loading, with high concentrations of chemical oxygen demand (COD), biochemical oxygen demand (BOD), and total solids (TS), as well as a low $\mathrm{pH}[3,11]$. In parts of Thailand, Brazil, Vietnam, and India, $\mathrm{CW}$ has been managed using stabilization ponds, aerobic systems, and AD [12]. Reported concerns associated with digestion of CW are the low nitrogen concentration and rapid acidification (low pH) of CW [13,14]. Co-digestion with a nitrogen-rich substrate, such as manure, could decrease the carbon-to-nitrogen $(\mathrm{C}: \mathrm{N})$ ratio and provide buffering capacity for stabilizing the $\mathrm{pH}$ in order to increase methane $\left(\mathrm{CH}_{4}\right)$ production. Previous studies have investigated cassava peels and pulps co-digested with livestock wastes [2,15], digestion of cassava starch effluent with separation of the acidogenic and methanogenic phases [16], re-circulation of methanogenic sludge [17], dolomitic limestone addition to increase alkalinity [13], and use of up flow anaerobic sludge blanket (UASB) digestion processing $[18,19]$.

Porous adsorbents, such as biochar, zeolite, and activated carbon, have been used to enhance $\mathrm{CH}_{4}$ production and general AD processes [20]. Biochar is a carbonaceous material obtained from agricultural biomass through pyrolysis and gasification. Mumme et al. reported that biochar is relatively cheaper to manufacture than other adsorbents, which has increased interest in land application of biochar, and more recently, inclusion in AD processing [21]. The use of biochar as an additive in $\mathrm{AD}$ has not been fully investigated, and no work has been done with biochar and AD of CW. There is potential for biochar to enhance the operational stability of the AD process and increase the quality of the digestate produced.

Zeolite has also been reported to possess favorable characteristics for microorganism adhesion [22], with the capacity to induce ion exchange during $\mathrm{AD}$ due to the presence of $\mathrm{Na}^{+}, \mathrm{Ca}^{2+}$, and $\mathrm{Mg}^{2+}$ cations in its crystalline structure. These properties could be useful for improving AD of wastewaters with high concentrations of nitrogen, such as poultry manure, as it prevents process inhibition. Application of natural zeolites as support media in digesters treating wastewaters has been reported to increase microbial population density and provide greater opportunity for microbial growth and attachment, cross feeding, co-metabolism, and interspecies hydrogen and proton transfer [22].

A prior study by Montalvo et al. reported that the addition of natural zeolite at doses between 2 and $4 \mathrm{~g} / \mathrm{L}$ increased $\mathrm{CH}_{4}$ production, with increasing inhibition at doses $>6 \mathrm{~g} / \mathrm{L}$ [23]. The use of porous materials, such as natural zeolites, to create surface area for microbial communities and increase retention of high biomass concentrations in the digestion of wastewater has been documented [22]. Zeolite was employed to enhance energy recovery, in the form of hydrogen $\left(\mathrm{H}_{2}\right)$, from cassava-ethanol wastewater during the dark fermentation process. [24]. To our knowledge, zeolite additions have not been used during the digestion of $\mathrm{CW}$ to enhance $\mathrm{CH}_{4}$ production.

General implementation and adoption of large-scale biogas technology in most African countries have been limited due to the high costs associated with investments and operations of AD systems [25], especially when there is an additional cost of transporting wastes to offsite AD reactors. The availability of agricultural biomass, which is abundant in the rural cassava industry, along with the large volume of CW generated daily in this industry, would provide larger quantities of organic material to be treated onsite using AD. This study focused on investigating the impact of the co-digestion of $\mathrm{CW}$ with selected livestock manures and porous adsorbents on biogas production for potential implementation and adoption in cassava industries. The objectives of the study were to: (1) characterize cassava wastewater as a substrates for $\mathrm{AD}$ and identify appropriate substrates for co-digestion, (2) investigate the $\mathrm{CH}_{4}$ potential of cassava digestion, with and without co-digestion with manure, biochar, and zeolite, in terms of cumulative production and retention time, (3) characterize the wastewater transformations during digestion in terms of organic and nutrient transformations, and (4) analyze the economic viability and environmental impact of employing digestion for the rural cassava industry. 


\section{Materials and Methods}

\subsection{Substrate and Inoculum Collection and Preparation}

\subsubsection{Cassava Wastewater Substrate}

The cassava tubers were obtained from a farmer's market in Adelphi, Maryland, USA. The cassava tubers were manually peeled and soaked for 5 days in the laboratory using $1 \mathrm{~L} / \mathrm{kg}$ of deionized water to replicate the rural cassava processing steps for ' $f u f u$ ' production, a popular African dish derived from fermented cassava paste. Fermented tubers were manually squeezed, and the cassava wastewater (CW) was collected and used for the experiments. The substrate characteristics and the experiment design are given in Tables 1 and 2. The CW had a COD range of 29.8-33.4 g/L, volatile solids (VS) of $17.3 \mathrm{~g} / \mathrm{kg}$, total solids (TS) of $17.8 \mathrm{~g} / \mathrm{kg}$, and a $\mathrm{pH}$ of 5.5 .

Table 1. Experimental design showing grams (g) of substrate addition into each triplicate $250 \mathrm{~mL}$ reactor.

\begin{tabular}{|c|c|c|c|c|c|c|c|}
\hline Treatment & $\begin{array}{c}\text { Cassava } \\
\text { Wastewater } \\
(\mathrm{CW})(\mathrm{g})\end{array}$ & $\begin{array}{c}\text { Zeolite } \\
\text { (ZEO) } \\
\text { (g) }\end{array}$ & $\begin{array}{c}\text { Biochar } \\
\text { (B-Char) } \\
\text { (g) }\end{array}$ & $\begin{array}{c}\text { Poultry } \\
\text { Litter (PL) } \\
\text { (g) }\end{array}$ & $\begin{array}{c}\text { Dairy } \\
\text { Manure } \\
\text { (DM) (g) }\end{array}$ & $\begin{array}{c}\text { Inoculum } \\
\text { (g) }\end{array}$ & Water $(\mathrm{g})$ \\
\hline $\mathrm{CW}+\mathrm{PL}+\mathrm{ZEO}(\mathrm{HC})$ & 28.9 & 3.4 & 0.0 & 0.8 & 0.0 & 92.1 & 28.2 \\
\hline $\mathrm{CW}+\mathrm{PL}+\mathrm{B}-\mathrm{Char}(\mathrm{HC})$ & 28.9 & 0.0 & 3.4 & 0.8 & 0.0 & 92.1 & 28.2 \\
\hline CW:PL (1:1) & 28.9 & 0.0 & 0.0 & 0.8 & 0.0 & 92.1 & 28.2 \\
\hline CW:PL (2:1) & 38.6 & 0.0 & 0.0 & 0.5 & 0.0 & 92.1 & 18.9 \\
\hline $\mathrm{CW}+\mathrm{DM}+\mathrm{ZEO}(\mathrm{HC})$ & 28.9 & 3.4 & 0.0 & 0.0 & 4.4 & 92.1 & 24.7 \\
\hline CW:DM $(1: 1)$ & 28.9 & 0.0 & 0.0 & 0.0 & 4.4 & 92.1 & 24.7 \\
\hline CW:DM (2:1) & 38.6 & 0.0 & 0.0 & 0.0 & 2.9 & 92.1 & 16.5 \\
\hline $\mathrm{CW}+\mathrm{ZEO}(\mathrm{HC})$ & 57.8 & 0.3 & 0.0 & 0.0 & 0.0 & 92.1 & 0.1 \\
\hline $\mathrm{CW}+\mathrm{ZEO}(\mathrm{HC})$ & 57.8 & 1.5 & 0.0 & 0.0 & 0.0 & 92.1 & 0.1 \\
\hline CW + B-Char (LC) & 57.8 & 0.0 & 0.3 & 0.0 & 0.0 & 92.1 & 0.1 \\
\hline $\mathrm{CW}+\mathrm{B}-\mathrm{Char}(\mathrm{HC})$ & 57.8 & 0.0 & 1.5 & 0.0 & 0.0 & 92.1 & 0.1 \\
\hline CW-only & 57.8 & 0.0 & 0.0 & 0.0 & 0.0 & 92.1 & 0.1 \\
\hline Inoculum-only & 0.0 & 0.0 & 0.0 & 0.0 & 0.0 & 92.1 & 0.0 \\
\hline
\end{tabular}

Table 2. Characterization of the substrates, cassava wastewater (CW), poultry litter (PL), and dairy manure (DM) and the inoculum source, including total solids (TS), volatile solids (VS), chemical oxygen demand (COD), $\mathrm{pH}$, total Kjeldahl nitrogen (TKN), total phosphorus (TP), and the carbon to nitrogen ratio $(\mathrm{C}: \mathrm{N})$.

\begin{tabular}{cccccccc}
\hline & TS (g/kg) & VS (\% TS) & COD (g/L) & pH & $\begin{array}{c}\text { TKN } \\
(\mathbf{m g} \mathbf{N} / \mathbf{L})\end{array}$ & $\begin{array}{c}\text { TP } \\
\text { (mg P/L) }\end{array}$ & C:N Ratio \\
\hline CW & $17.8 \pm 0.7$ & $97.2 \pm 0.7$ & $33.7 \pm 0.8$ & 5.53 & 375 & 222 & 27.8 \\
PL & $776 \pm 1$ & $80.0 \pm 0.2$ & NA & 8.25 & 3675 & 1245 & 13.0 \\
DM & $131 \pm 2$ & $87.3 \pm 0.6$ & NA & 7.33 & 3450 & 603 & 15.2 \\
Inoculum & $29.5 \pm 0.1$ & $73.6 \pm 7.0$ & $25.1 \pm 0.3$ & 7.55 & 3050 & 1225 & 3.91 \\
\hline
\end{tabular}

\subsubsection{Dairy and Poultry Manure Substrates and Inoculum Source}

The dairy manure (DM) used as a co-substrate was obtained from the 100-cow dairy at the US Department of Agriculture (USDA) Beltsville Agricultural Research Service (ARS) in Beltsville, MD. Poultry litter (PL) was obtained from a poultry (broiler) farm at the University of Maryland Extension-Talbot county, Easton Maryland. The poultry litter consisted of poultry droppings and beddings from wood shavings. Both manure substrates were collected onsite and stored at $4{ }^{\circ} \mathrm{C}$ before use. The inoculum used for the experiment was digestate of a complete mixed wastewater sludge digester (Alexandria, VA, USA) and was stored at $4{ }^{\circ} \mathrm{C}$ prior to use.

\subsubsection{Biochar and Zeolite Additives}

Two porous materials, biochar (B-Char) and clinoptitolite zeolite (ZEO), were added to the CW as co-treatments. The biochar (B-Char) substrate was derived from corn stover prepared through pyrolysis under an $\mathrm{O}_{2}$-free atmosphere at $500{ }^{\circ} \mathrm{C}$, with a holding time of $10 \mathrm{~min}$ (ArtiCHAR, Prairie 
City, Iowa, USA). The biochar particle size varied from $841 \mathrm{~mm}$ to $<74 \mathrm{~mm}$, with a VS and TS of 690 and $980 \mathrm{~g} / \mathrm{kg}$, respectively. The zeolite was a high purity $97 \%$ clinoptilolite zeolite produced at Amargosa Valley (Nye county, NV, USA). The zeolite used was in the form of granules with an angular shape and gray color. The pore diameter was between 4.0-7.0 angstroms.

\subsection{Experimental Design}

A batch digestion experiment was conducted based on the biochemical methane potential (BMP) test following methods by Moody et al. [26]. The digestion tests were conducted at the University of Maryland's Department of Environmental Science and Technology (ENST) Water Quality Laboratory (College Park, MD USA). Prior to starting BMP tests, the TS and VS for CW, PL, DM, and inoculum were determined and used to combine the co-substrate ratios based on VS. The experiment was designed for 16 treatments, with three replicates for each treatment (48 total digestion reactors). Each digestion reactor consisted of a $250 \mathrm{~mL}$ serum bottle, with the substrates and inoculum loaded at a 2:1 inoculum to substrate ratio (ISR) based on VS and operated in mesophilic conditions $\left(35^{\circ} \mathrm{C}\right)$. For all treatments, an equal volume of inoculum $(92.1 \mathrm{~g})$ was added to each triplicate reactor.

The biochar (B-Char) and zeolite (ZEO) treatments were prepared using a low concentration (LC) ( $0.5 \mathrm{~g}$ adsorbent/g TS of substrate) and a high concentration (HC) (3 g adsorbent/g TS of substrate) added to $57.82 \mathrm{~g} \mathrm{CW}$. For the manure co-digestion treatments, $3.42 \mathrm{~g}$ of PL and $3.26 \mathrm{~g}$ of DM were digested alone and co-digested with $28.91 \mathrm{~g} \mathrm{CW}$ with and without the HC of ZEO. Additionally, PL was co-digested with $28.91 \mathrm{~g} \mathrm{CW}$ and the $\mathrm{HC}$ of B-Char. Inoculum-only reactors were also incubated, and the $\mathrm{CH}_{4}$ production from the inoculum was subtracted from each treatment to account for residual $\mathrm{CH}_{4}$ production from organics in the inoculum.

Prior to incubation, the headspace in each vessel was purged with $\mathrm{N}_{2}$ for three minutes to ensure anaerobic conditions and immediately capped with a rubber septum, and the bottles were placed on a shaker $(120 \mathrm{rpm})$ in a controlled environmental chamber at $35^{\circ} \mathrm{C}$ for 48 days. The daily biogas volume was measured by volumetric displacement using a graduated, gas-tight, wet-tipped $50 \mathrm{~mL}$ glass syringe inserted through the top of the rubber septum. Biogas production was quantified volumetrically at normal temperature and pressure conditions using a glass gas-tight syringe, equilibrated to atmospheric pressure [26]. All $\mathrm{CH}_{4}$ production values are reported in normal temperature and pressure conditions (1 atm and $\left.20^{\circ} \mathrm{C}\right)$.

\subsection{Analytical Methods}

The $\mathrm{pH}$ of substrates and inoculum were determined with an Accumet $\mathrm{AB} 15 \mathrm{pH}$ meter (Fisher Scientific, Hampton, NH). For all samples, TS (Method 2540B) and VS (Method 2540E) concentrations were determined using standard methods for the examination of water and wastewater [27]. Total Kjeldahl nitrogen (TKN) and total phosphorus (TP) samples were analyzed on a Lachat autoanalyzer (Quikchem 8500, Hach Company, Loveland, CO, USA) using QuikChem methods 13-107-06-2-D for TKN and 13-115-01-1-B for TP. The COD concentration was measured using a Hach DR 5000 spectrophotometer (Hach Company, Loveland, CO, USA).

The carbon content of the CW, PL, DM, and inoculum were calculated using the equation from Adams et al. [28], where \% Carbon $=\%$ VS/1.8.

Biogas was analyzed for $\mathrm{CH}_{4}$ and $\mathrm{CO}_{2}$ content by injecting $0.10 \mathrm{~mL}$ of gas sample using a luer-lock, gas-tight syringe into an Agilent HP 7890 A gas chromatograph (Agilent Technologies, Santa Clara, CA, USA) equipped with a thermal conductivity detector (TCD) and single HP porous layer open tubular (PLOT) Q column with an injection temperature of $250^{\circ} \mathrm{C}$, a detector temperature of $250^{\circ} \mathrm{C}$, an oven temperature of $60^{\circ} \mathrm{C}$, and conveyed using He gas at a flow rate of $8.6 \mathrm{~mL} \mathrm{He} / \mathrm{min}$ [10].

\subsection{Statistical Analysis}

Cumulative $\mathrm{CH}_{4}$ production was analyzed using analysis of variance (ANOVA) to determine significantly differences, with $p$-values $<0.05$ considered significant. Tukey's honestly significant 
difference (HSD) post-hoc tests were performed for multiple comparisons between variables based on different digestion periods during the 48 days of the experiment. All results presented in the tables and charts are average values with standard error (SE).

\section{Results and Discussion}

\subsection{Characterization of Substrate and Inoculum}

The $\mathrm{pH}$ of the $\mathrm{CW}$ substrate was between 5.5 and 6.5 (Table 2). Some studies have reported lower $\mathrm{pH}$ values for $\mathrm{CW}$, ranging from 3.9-4.5 [29]. The $\mathrm{pH}$ of mixed substrates before and after AD was within the ideal $\mathrm{pH}$ range (6.5-8) for $\mathrm{CH}_{4}$ production [30]. The TS and VS of the cassava wastewater (17.8 and $17.3 \mathrm{~g} / \mathrm{L}$, respectively) was $75.8 \%$ and $60.4 \%$ lower than PL respectively, and 11.3 and $9.7 \%$ lower than DM, respectively. As the CW was a liquid wastewater, it was a more dilute waste stream than the manure substrates and had comparatively less TS and VS.

The TKN and TP of the CW were 375 and $222 \mathrm{mg} / \mathrm{L}$ respectively (Table 2), whereas, the PL had higher TKN and TP values (3675 and $1245 \mathrm{mg} / \mathrm{L}$, respectively), which were similar to DM (3450 and $603 \mathrm{mg} / \mathrm{L}$, respectively). The low nitrogen content of CW observed in this study was consistent with findings from others $\mathrm{CW}$ studies $[1,2,8]$. The C:N ratio of the $\mathrm{CW}$ substrate was 27.8 , which was similar to the value 29.1 reported by Lin et al. [31]. The carbon to nitrogen ratio is a key factor affecting anaerobic digestion [32], with C:N ratios between 25 and 30 reported as the most suitable for $\mathrm{CH}_{4}$ production $[2,31]$. The $\mathrm{C}: \mathrm{N}$ ratio for PL and DM in this experiment was 13.0 and 15.2 respectively, which were lower than the optimal conditions, while the $\mathrm{CW}$ was higher. When the substrates were combined, the C:N ratio of the mixtures were 20.4 and 21.1, for PL and DM, respectively.

\subsection{Effect of Livestock Manure Co-Digestion with Cassava Wastewater on Biogas Production}

\subsubsection{Cumulative $\mathrm{CH}_{4}$ Production Based on VS Addition into the Digestion Reactor}

After 48 days of digestion, the cumulative $\mathrm{CH}_{4}$ production (on a per $\mathrm{g}$ VS-basis) from $\mathrm{CW}$-only (620 $\mathrm{mL} \mathrm{CH}_{4} / \mathrm{g}$ VS) was $15.8 \%$ higher than co-digestion of $\mathrm{CW}: \mathrm{DM}$ at a 2:1 ratio $\left(522 \mathrm{~mL} \mathrm{CH}_{4} / \mathrm{g} \mathrm{VS}\right.$; $p$-value $<0.001$; Figure 1; Table 3). The $\mathrm{CW}$-only digestion had $5.8 \%$ higher $\mathrm{CH}_{4}$ production than $\mathrm{CW}: \mathrm{PL}$ at a 2:1 ratio $\left(590 \mathrm{~mL} \mathrm{CH}_{4} / \mathrm{g} \mathrm{VS}\right)$, but this difference was not statistically significant ( $p$-value $\left.=0.864\right)$. Similarly, CW-only was $14.4 \%$ and $25.6 \%$ higher respectively, than CW co-digested at a 1:1 ratio with $\mathrm{DM}$ and PL (461 and $531 \mathrm{~mL} \mathrm{CH}_{4} / \mathrm{g}$ VS; $p$-values $<0.001$ and 0.001 , respectively).

Table 3. Reductions in volatile solids (VS) and chemical oxygen (COD) during digestion for the substrate and inoculum in each reactor. The cumulative methane $\left(\mathrm{CH}_{4}\right)$ production is given using two normalizations: per g VS added and per $\mathrm{g}$ of total substrate added. Superscript letters (a through g) indicate significant differences within each column at $p$-value $<0.05$.

\begin{tabular}{|c|c|c|c|c|c|}
\hline Substrate & $\begin{array}{c}\text { VS Reduction } \\
(\%)\end{array}$ & $\begin{array}{l}\text { Influent COD } \\
\qquad(\mathrm{g} / \mathrm{L})\end{array}$ & $\begin{array}{c}\text { COD } \\
\text { Reduction (\%) }\end{array}$ & $\begin{array}{c}\text { Cumulative } \mathrm{CH}_{4} \\
\left(\mathrm{~mL} \mathrm{CH}_{4} / \mathrm{g} \text { VS) }\right.\end{array}$ & $\begin{array}{c}\text { Cumulative } \mathrm{CH}_{4} \\
\text { (mL CH} 4 / g \text { Substrate) }\end{array}$ \\
\hline CW-only & $65.5 \pm 0.1^{\mathrm{a}}$ & $29.6 \pm 0.4^{\mathrm{ab}}$ & $40.6 \pm 2.9^{a}$ & $620 \pm 6.0^{\mathrm{abc}}$ & $10.7 \pm 0.1^{\mathrm{a}}$ \\
\hline $\mathrm{CW}+\mathrm{B}-\mathrm{Char}(\mathrm{HC})$ & $37.5 \pm 0.1^{b}$ & $41.9 \pm 0.7^{c}$ & $23.6 \pm 7.5^{b}$ & $611 \pm 27^{b c}$ & $10.6 \pm 0.5^{\mathrm{a}}$ \\
\hline $\mathrm{CW}+\mathrm{B}-\mathrm{Char}(\mathrm{LC})$ & $62.7 \pm 0.3^{a}$ & $34.9 \pm 2.4^{\mathrm{d}}$ & $48.8 \pm 5.3^{\mathrm{a}}$ & $611 \pm 16^{\mathrm{a}}$ & $10.6 \pm 0.3^{\mathrm{a}}$ \\
\hline $\mathrm{CW}+\mathrm{ZEO}(\mathrm{HC})$ & $66.0 \pm 1.9^{a}$ & $33.7 \pm 0.8^{\mathrm{de}}$ & $49.2 \pm 1.6^{\mathrm{a}}$ & $653 \pm 4^{\mathrm{a}}$ & $11.3 \pm 0.1 \mathrm{ab}$ \\
\hline $\mathrm{CW}+\mathrm{ZEO}(\mathrm{LC})$ & $66.2 \pm 2.6^{\mathrm{a}}$ & $32.8 \pm 1.0$ de & $46.2 \pm 1.0^{\mathrm{a}}$ & $634 \pm 6^{\mathrm{ab}}$ & $11.0 \pm 0.1 \mathrm{ab}$ \\
\hline $\mathrm{CW}+\mathrm{PL}+\mathrm{B}-\mathrm{Char}(\mathrm{HC})$ & $6.88 \pm 1.4^{c}$ & $41.6 \pm 0.6^{c}$ & $-31.1 \pm 1.2 * \mathrm{c}$ & $471 \pm 16^{\mathrm{d}}$ & $15.9 \pm 0.5^{\text {dce }}$ \\
\hline $\mathrm{CW}+\mathrm{PL}+\mathrm{ZEO}(\mathrm{HC})$ & $61.4 \pm 0.6^{\mathrm{a}}$ & $31.6 \pm 2.1^{\text {ae }}$ & $44.0 \pm 3.4^{\mathrm{a}}$ & $518 \pm 8^{\mathrm{e}}$ & $17.4 \pm 0.3^{\text {dce }}$ \\
\hline $\mathrm{CW}+\mathrm{DM}+\mathrm{ZEO}(\mathrm{HC})$ & $57.3 \pm 0.2^{\mathrm{a}}$ & $25.8 \pm 0.3^{f}$ & $21.9 \pm 6.1^{b}$ & $473 \pm 5^{d}$ & $14.2 \pm 0.2 \mathrm{dbe}$ \\
\hline CW:PL (1:1) & $63.5 \pm 0.6^{\mathrm{a}}$ & $28.8 \pm 2.0^{\mathrm{b}}$ & $42.7 \pm 3.2^{\mathrm{a}}$ & $531 \pm 10^{\mathrm{e}}$ & $17.9 \pm 0.3^{c}$ \\
\hline CW:PL (2:1) & $64.8 \pm 0.5^{a}$ & $28.9 \pm 0.3^{b}$ & $39.6 \pm 4.9^{a}$ & $590 \pm 6^{c}$ & $15.1 \pm 0.2^{\text {dce }}$ \\
\hline CW:DM (1:1) & $59.9 \pm 1.0^{\mathrm{a}}$ & $29.5 \pm 0.9^{a b}$ & $37.4 \pm 0.5^{\mathrm{a}}$ & $461 \pm 17^{d}$ & $13.8 \pm 0.5^{\text {abe }}$ \\
\hline CW:DM (2:1) & $63.4 \pm 0.3^{a}$ & $32.5 \pm 1.9^{\mathrm{e}}$ & $47.8 \pm 2.7^{\mathrm{a}}$ & $522 \pm 14^{\mathrm{e}}$ & $12.6 \pm 0.3^{\text {abe }}$ \\
\hline DM-only & $48.4 \pm 5.3^{d}$ & $28.0 \pm 0.7^{b f}$ & $20.9 \pm 2.9^{b}$ & $100 \pm 5^{f}$ & $22.9 \pm 1.1^{\mathrm{f}}$ \\
\hline PL-only & $63.0 \pm 8.4^{\mathrm{a}}$ & $28.2 \pm 1.3^{b}$ & $20.7 \pm 0.1^{b}$ & $156 \pm 3 g$ & $193 \pm 4^{g}$ \\
\hline
\end{tabular}

* a negative value indicates a percent increase due to addition of biochar not included in pre-COD. 

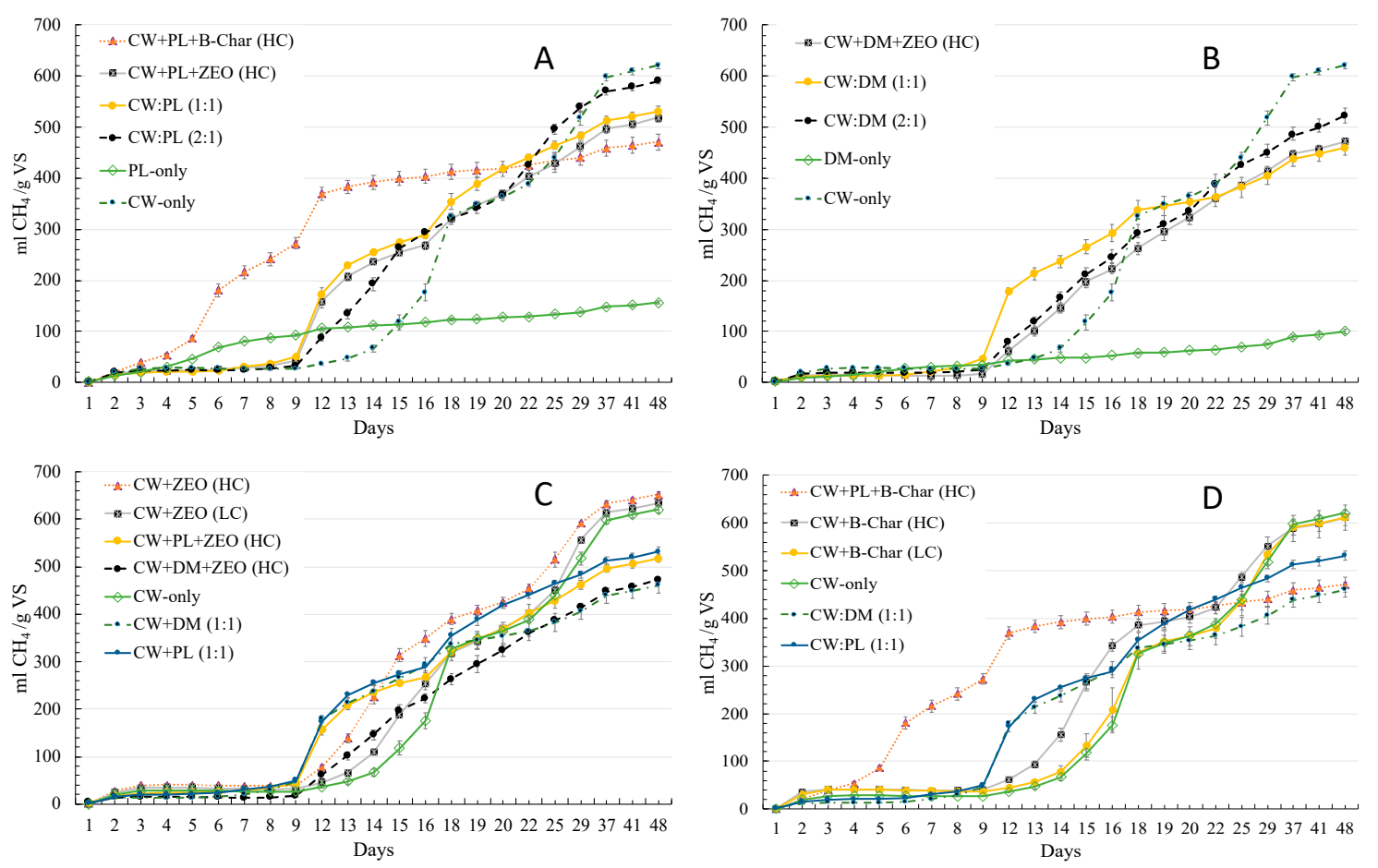

Figure 1. Cumulative $\mathrm{CH}_{4}$ production based on volatile solids (VS) added to each reactor for cassava wastewater (CW) digested alone and co-digested with poultry litter (PL) shown in (A), co-digestion with dairy manure (DM) shown in (B), and co-digestion with zeolite (ZEO) and biochar (B-Char) at low and high concentrations (LC and HC) shown in (C) and (D), respectively.

When $\mathrm{CH}_{4}$ production is normalized on a VS basis, the efficiency of the organic material to $\mathrm{CH}_{4}$ conversion process is shown. These results show that $\mathrm{CW}$ can be co-digested or digested alone, and co-digestion of $\mathrm{CW}$ with manure resulted in similar or slightly lower $\mathrm{CH}_{4}$ production efficiency values (5.8\%-25.6\% decrease with co-digestion). It should be noted that the inoculum included in the digestion reactor helped to lower the $\mathrm{C}: \mathrm{N}$ ratio from 27.8 in the $\mathrm{CW}$ substrate to 21.7 in the digestion reactor with the inoculum and $\mathrm{CW}$ mixture, with an increase in the $\mathrm{pH}$ value from 5.53 to 7.75 due to inoculum inclusion. The significance of $\mathrm{pH}$ as a key determining factor for $\mathrm{AD}$ process, especially in full-scale continuous reactors were highlighted in Calabrò et al. [33,34]. In field conditions, it would be important to have a viable inoculum source for initiating digestion and to consider a co-digestion material that can help to neutralize the low $\mathrm{pH}$ and is high in nitrogen to ensure that the microbes are not nitrogen-limited.

\subsubsection{Cumulative $\mathrm{CH}_{4}$ Production Based on the Mass of Substrate Added to the Digestion Reactor}

Due to the high VS concentration of the manure substrates, the PL-only reactors had an order a magnitude higher $\mathrm{CH}_{4}$ production on a mass basis (193 $\mathrm{mL} \mathrm{CH}_{4} / \mathrm{g}$ substrate) than DM-only (22.9 $\mathrm{mL}$ $\mathrm{CH}_{4} / \mathrm{g}$ substrate) and all CW reactors (Table 3). The DM and PL manure substrates had $84.8 \%$ to $97.2 \%$ higher VS concentrations respectively, than the CW substrate (Table 2). Digestion of CW yielded 83.9\% and $74.8 \%$ more cumulative $\mathrm{CH}_{4}$ (on a VS-basis) than DM-only and PL-only digestion (100 and $156 \mathrm{~mL}$ $\mathrm{CH}_{4} / \mathrm{g}$ VS, respectively; Table 2), as the organic matter in the $\mathrm{CW}$ substrate was converted into $\mathrm{CH}_{4}$ more efficiently than the manure substrates, likely due to the more recalcitrant nature of the VS in the complex manure substrates compared to the cassava wastewater. The CW:PL (1:1) had the highest $\mathrm{CH}_{4}$ production (17.9 $\mathrm{mL} \mathrm{CH}_{4} / \mathrm{g}$ substrate) of the $\mathrm{CW}$ co-digestion treatments (on a mass basis). The PL co-substrate had higher $\mathrm{CH}_{4}$ production efficiencies than $\mathrm{CW}$ co-digested with DM at both the 1:1 and $2: 1$ ratios ( $p$-values $=0.017$ and 0.025 , respectively), indicating that a continuously-fed CW digestion system would benefit from co-digesting with PL due to the high organic loading of the PL substrate. 


\subsubsection{Cumulative $\mathrm{CH}_{4}$ Production Based on Digestion Period}

While the overall $\mathrm{CH}_{4}$ production efficiency from the $\mathrm{CW}$-only was higher than the manure substrates, the $\mathrm{CW}$-only treatment produced $118 \mathrm{~mL} \mathrm{CH}_{4} / \mathrm{g}$ VS $\left(19 \%\right.$ of the cumulative $\left.\mathrm{CH}_{4}\right)$ in the first 15 days of the 48-day digestion period (Table 4; Figure 2). During this first third of the digestion period (Days 1-15), the $\mathrm{CH}_{4}$ production from the $\mathrm{CW}$-only treatment was significantly lower (38.6\%) than CW:DM at 1:1 (265 $\left.\mathrm{mL} \mathrm{CH}_{4} / \mathrm{g} \mathrm{VS}\right)$ and 32.6\% lower CW:PL at 1:1 $\left(274 \mathrm{~mL} \mathrm{CH}_{4} / \mathrm{g} \mathrm{VS}\right.$; $p$-values $\left.<0.001\right)$. When the ratio of $\mathrm{CW}$ to manure was doubled (2:1), the $\mathrm{CH}_{4}$ production from Days 1-15 in the CW:PL (2:1) and CW:DM (2:1) reactors was 263 and $211 \mathrm{~mL} \mathrm{CH}_{4} / \mathrm{g}$ VS respectively, which was 25.7 and $21.5 \%$ higher than CW-only ( $p$-value $<0.001$ and 0.002 , respectively).

Table 4. Cumulative methane $\left(\mathrm{CH}_{4}\right)$ during the 48-day digestion period for designated time periods, with the percent of the total cumulative $\mathrm{CH}_{4}$ production in parenthesis. Superscript letters (a through g) significant differences within each column at $p$-value $<0.05$.

\begin{tabular}{|c|c|c|c|c|c|}
\hline \multirow{2}{*}{ Treatment } & \multicolumn{5}{|c|}{ Cumulative $\mathrm{CH}_{4}$ in $\mathrm{mL} \mathrm{CH}_{4} / \mathrm{g}$ VS and (\% of Total $\mathrm{CH}_{4}$ Production) } \\
\hline & 9 Days & 15 Days & 20 Days & 37 Days & 48 Days \\
\hline CW-only & $26.8(4.3 \%)$ abc & $118(19 \%)^{a}$ & $364(58.7 \%)^{a b}$ & $598(96.4 \%)$ abc & $620(100 \%))^{a b c}$ \\
\hline $\mathrm{CW}+\mathrm{B}-\mathrm{Char}(\mathrm{HC})$ & $39.9(6.5 \%)$ adef & $265(43.4 \%)^{b}$ & $403(66 \%)$ bc & $589(96.4 \%)$ bc & $611(100 \%)$ bc \\
\hline $\mathrm{CW}+\mathrm{B}-\mathrm{Char}(\mathrm{LC})$ & $37.8(6.2 \%)$ acdef & $133(21.7 \%)^{\text {a }}$ & $363(59.4 \%)^{\mathrm{a}}$ & $591(96.8 \%) b c$ & $611(100 \%)$ bc \\
\hline $\mathrm{CW}+\mathrm{ZEO}(\mathrm{HC})$ & $39.3(6 \%)$ acdef & $314(48.1 \%)^{c}$ & $425(65.2 \%)^{c}$ & $634(97.1 \%)^{a}$ & $653(100 \%)^{a}$ \\
\hline $\mathrm{CW}+\mathrm{ZEO}(\mathrm{LC})$ & $31.5(5 \%)$ ace & $189(29.8 \%)^{d}$ & $370(58.4 \%)^{a b}$ & $614(96.8 \%)^{a b}$ & $634(100 \%)^{a b}$ \\
\hline $\mathrm{CW}+\mathrm{PL}+\mathrm{B}-\mathrm{Char}(\mathrm{HC})$ & $273(57.9 \%)^{g}$ & $400(84.8 \%)^{\mathrm{e}}$ & $419(88.9 \%)^{c}$ & $459(97.4 \%)$ de & $471(100 \%)^{d}$ \\
\hline $\mathrm{CW}+\mathrm{PL}+\mathrm{ZEO}(\mathrm{HC})$ & $43.2(8.3 \%)$ def & $255(49.2 \%)^{b}$ & $370(71.4 \%)^{a b}$ & $497(95.9 \%)^{f}$ & $518(100 \%)^{e}$ \\
\hline $\mathrm{CW}+\mathrm{DM}+\mathrm{ZEO}(\mathrm{HC})$ & $17(3.6 \%)^{b}$ & $197(41.7 \%)^{d}$ & $323(68.5 \%)^{d}$ & $447(94.7 \%)$ de & $473(100 \%)^{d}$ \\
\hline CW:PL (1:1) & $49.8(9.4 \%)^{c}$ & $274(51.6 \%)$ bc & $419(78.8 \%)^{c}$ & $513(96.5 \%)^{f}$ & $531(100 \%)^{e}$ \\
\hline CW:PL (2:1) & $32.6(5.5 \%)$ acde & $263(44.7 \%)^{b}$ & $366(62 \%)^{b a}$ & $571(96.8 \%)^{c}$ & $590(100 \%)^{c}$ \\
\hline CW:DM (1:1) & $46.5(10.1 \%) \mathrm{df}$ & $265(57.6 \%)^{b}$ & $353(76.6 \%)$ da & $439(95.3 \%)^{d}$ & $461(100 \%)^{d}$ \\
\hline CW:DM (2:1) & $25.4(4.9 \%) b c$ & $211(40.5 \%)^{d}$ & $336(64.3 \%)$ da & $484(92.8 \%)$ ef & $522(100 \%)^{e}$ \\
\hline DM-only & $34.8(34.6 \%)$ acde & $48.4(48.2 \%)^{\mathrm{f}}$ & $62.6(62.3 \%)^{e}$ & $89.1(88.8 \%)^{g}$ & $100(100 \%)^{f}$ \\
\hline PL-only & $92.3(59 \%)^{\mathrm{h}}$ & $114(72.9 \%)^{\mathrm{a}}$ & $128(82 \%)^{f}$ & $148(95 \%)^{h}$ & $156(100 \%) g$ \\
\hline
\end{tabular}

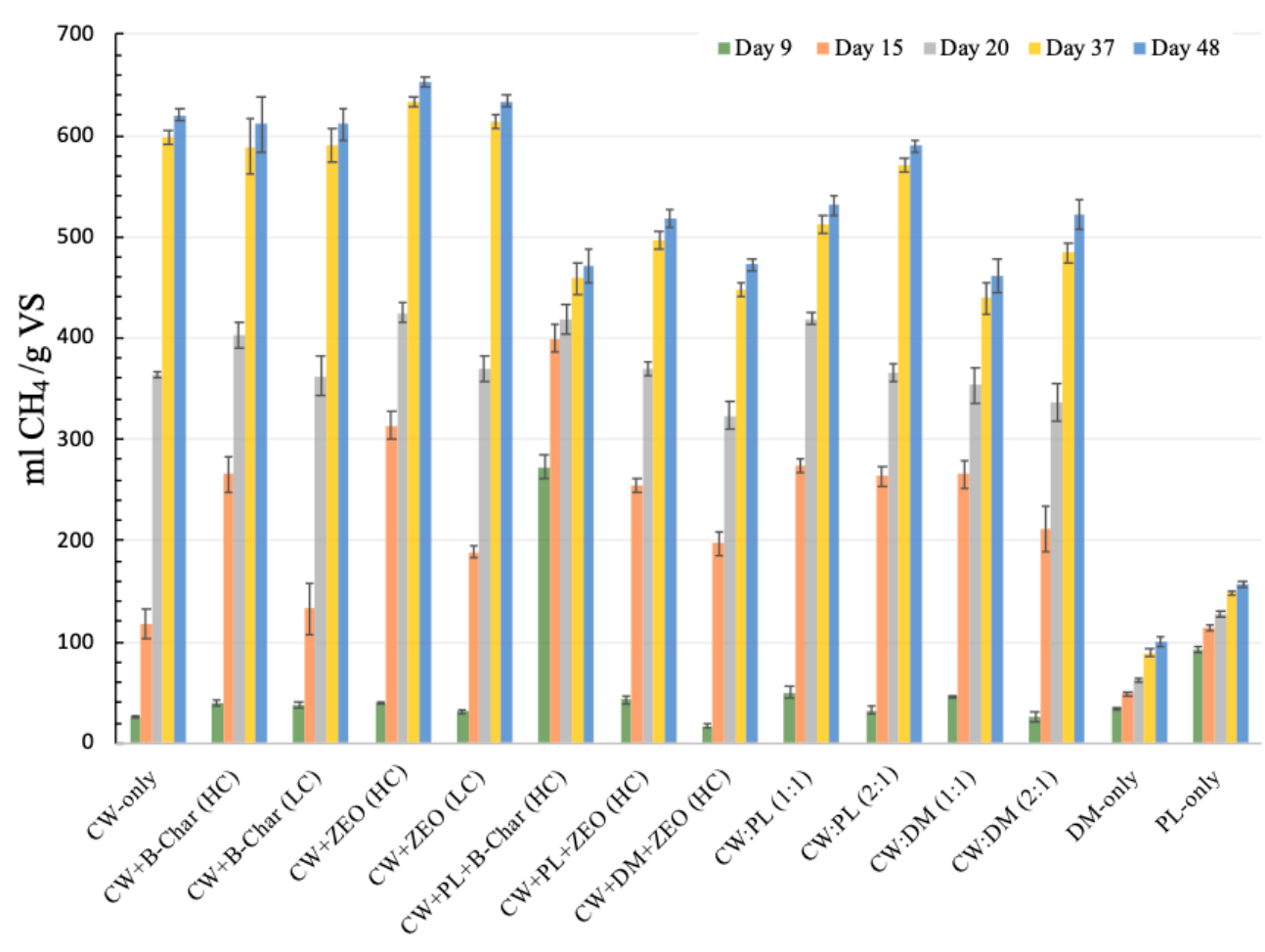

Figure 2. Cumulative methane $\left(\mathrm{CH}_{4}\right)$ production based on volatile solids (VS) added to each reactor for cassava wastewater (CW) digested alone and co-digested with poultry litter (PL), dairy manure (DM), zeolite (ZEO), and biochar (B-Char) at low and high concentrations (LC and HC) at five time points (Days 9, 15, 20,37, and 48) in the 48-day digestion period. 
There was no significant difference in cumulative $\mathrm{CH}_{4}$ production between $\mathrm{CW}: \mathrm{PL}$ at the 1:1 and 2:1 ratios ( $p$-value $=0.087)$. The $\mathrm{CW}: \mathrm{PL}(2: 1)$ had $4.1 \%$ less $\mathrm{CH}_{4}$ in the first 15 days of digestion, showing a slight decrease in lag phase during digestion without a significant effect on the overall $\mathrm{CH}_{4}$ production potential (Figure 2). A similar trend was observed when comparing the CW:DM at 1:1 and 2:1 ratios, with 265 and $211 \mathrm{~mL} \mathrm{CH}_{4} / \mathrm{g}$ VS respectively, in the first 15 days of digestion, which were not significantly different ( $p$-value of 0.061 ).

Generally, co-digestion of CW with PL or DM reduced the lag phase for $\mathrm{CH}_{4}$ production. The highest rate of $\mathrm{CH}_{4}$ production occurred within the first two weeks, which is consistent with the results from Witarsa and Lansing [30], where a large percentage of $\mathrm{CH}_{4}$ production from digestion of separated and unseparated dairy manure (DM) occurred in the first 16 days of a 216 day digestion period ( $40 \%$ and $36 \%$, respectively). Cassava wastewater (CW-only) generated $19 \%$ of the total cumulative $\mathrm{CH}_{4}$ in the first 15 days of our 48-day digestion period, while DM-only generated $48.2 \%$ of the total cumulative $\mathrm{CH}_{4}$ and $\mathrm{CW}$ :DM (1:1) generated $57.6 \%$ of the cumulative $\mathrm{CH}_{4}$ production in the first 15 days.

The observed increase in $\mathrm{CH}_{4}$ production with co-digestion of $\mathrm{CW}$ within the first two weeks was consistent with other findings, which emphasized the advantages of co-digestion over single digestion of substrates [2,32,35-37]. Panichnumsin et al. [2] examined the potential of co-digestion of cassava pulp and swine manure in a semi-continually fed stirred tank reactor in mesophilic conditions $\left(37^{\circ} \mathrm{C}\right)$ at a constant organic loading rate of $3.5 \mathrm{~kg} \mathrm{VS} / \mathrm{m}^{3} \mathrm{~d}$ for 15 days and reported a $41 \%$ increase in $\mathrm{CH}_{4}$ yield compared with digestion of swine manure alone. Similar to our study, a batch experiment conducted by Riano et al. [37] at $35^{\circ} \mathrm{C}$ for 55 days reported that co-digestion of winery wastewater (10-40\%) and swine manure increased $\mathrm{CH}_{4}$ production by $45-75 \%$ and improved digestion stability compared to digestion of swine manure alone.

Abouelenien et al. [35] co-digested, poultry manure (PM) with mixed agricultural wastes comprised of coconut wastes, cassava wastes, and coffee grounds. The cassava waste used in their study was root residue and wet cake from cassava, while our study utilized cassava wastewater. Similar to our study, co-digestion was conducted under mesophilic conditions $\left(35^{\circ} \mathrm{C}\right)$ and saw an increase in $\mathrm{CH}_{4}$ yield of up to $50 \%$ ( $506 \mathrm{~mL} \mathrm{CH}_{4} / \mathrm{g}$ VS) compared to PM-only after 40 days of digestion. Their results were comparable to our study, with cumulative $\mathrm{CH}_{4}$ production of $531 \mathrm{~mL} \mathrm{CH}_{4} / \mathrm{g}$ VS for CW:PL (1:1) after 48 days, which was significantly ( $p$-value $=0.001$ ) higher than PL-only, which yielded only $156 \mathrm{~mL}$ $\mathrm{CH}_{4} / \mathrm{g}$ VS. Contrary to our findings, Abouelenien et al. [37] reported an elongation of the lag phase due to co-digestion, which was attributed to the complex organic matter in the mixed agricultural wastes compared to the PM substrate. Whereas in our study, a reduction in lag phase was recorded due to the liquid state of the CW substrate, which was more readily accessible for the rate-limiting hydrolysis phase of digestion.

\subsection{Impact of Porous Adsorbent on AD of Cassava Wastewater}

\subsubsection{Zeolite Addition with Cassava Wastewater Digestion}

Digesting CW and a high concentration (HC) of zeolite (CW + ZEO-HC) produced the highest cumulative $\mathrm{CH}_{4}\left(653 \mathrm{~mL} \mathrm{CH}_{4} / \mathrm{g}\right.$ VS) for all treatments after 48 days, followed by the treatment with a lower concentration (LC) of zeolite (CW + ZEO-LC), which produced $634 \mathrm{~mL} \mathrm{CH}_{4} / \mathrm{g}$ VS, with no significant different between the two zeolite concentrations ( $p$-value $=1.00$; Figure 1; Table 2). The two porous adsorbents used in this study at the HC were also not significantly different $(p$-value $=0.50)$, with the cumulative $\mathrm{CH}_{4}$ produced from $\mathrm{CW}+\mathrm{ZEO}-\mathrm{HC}\left(653 \mathrm{~mL} \mathrm{CH}_{4} / \mathrm{g} \mathrm{VS}\right)$ only slightly higher than $\mathrm{CW}+\mathrm{B}-\mathrm{Char}-\mathrm{HC}\left(611 \mathrm{~mL} \mathrm{CH}_{4} / \mathrm{g} \mathrm{VS}\right)$.

After 9 days of digestion, a significantly higher percentage of the total $\mathrm{CH}_{4}$ production $(37.8 \%)$ was observed in CW + ZEO-HC compared to CW-only (Table 3; Figure 2). This observation is consistent with Milan et al., where doses of zeolite between 2 and $4 \mathrm{~g} / \mathrm{L}$ increased $\mathrm{CH}_{4}$ production of swine manure and of zeolite, while doses above $6 \mathrm{~g} / \mathrm{L}$ inhibited the process [38]. In our study, the effect of 
zeolite on digestion of CW, singly and co-digested with manure, the $3 \mathrm{~g} / \mathrm{L}$ of zeolite (CW + ZEO-HC) had $90.7 \%$ and $15.5 \%$ more $\mathrm{CH}_{4}$ production on Days 15 and 20 than $\mathrm{CW}$-only ( $p$-value $<0.001$ and 0.045 , respectively). The effect of zeolite addition was significant during the early stages of digestion process, up to the first three weeks. At Days 37 and 48, there was no significant difference between $\mathrm{CW}$-only and $\mathrm{CW}+\mathrm{ZEO}-\mathrm{HC}$, with the cumulative $\mathrm{CH}_{4}$ from $\mathrm{CW}+\mathrm{ZEO}-\mathrm{HC}$ only $5.1 \%$ higher than $\mathrm{CW}$-only ( $p$-values $=0.68$ and 0.82 , respectively).

\subsubsection{Biochar Addition with Cassava Wastewater Digestion}

Similarly, an increase in $\mathrm{CH}_{4}$ production with a shortened lag phase was observed due to biochar addition (Figure 2). The effect of biochar addition in reducing the lag phase in AD has been previously reported [39,40]. Jang et al. showed a $24.9 \%$ increase in cumulative $\mathrm{CH}_{4}\left(467 \mathrm{~mL} \mathrm{CH}_{4} / \mathrm{g} \mathrm{VS}\right)$ with $10 \mathrm{~g} / \mathrm{L}$ of biochar compared to $1 \mathrm{~g} / \mathrm{L}$ of biochar $\left(395 \mathrm{~mL} \mathrm{CH}_{4} / \mathrm{g} \mathrm{VS}\right.$ ) with mesophilic conditions and 40 days of digestion [40]. Our findings showed that on Day 15, CW + B-Char-HC had 76.8\% more $\mathrm{CH}_{4}$ production than the $\mathrm{CW}$-only treatment, which Jang et al. suggested was due to the high alkalinity of biochar enhancing $\mathrm{CH}_{4}$ production and shortening the lag phase [40].

Comparing the concentrations of porous adsorbent added, there was a significant difference in cumulative $\mathrm{CH}_{4}$ production between the low and high concentrations of biochar ( $p$-value $<0.001$ ) on Day 15 of digestion (Figure 2). In the first two weeks of digestion, $\mathrm{CW}+\mathrm{B}-\mathrm{Char}-\mathrm{HC}$ yielded $265 \mathrm{~mL}$ $\mathrm{CH}_{4} / \mathrm{g}$ VS, while CW + B-Char-LC yielded $133 \mathrm{~mL} \mathrm{CH}_{4} / \mathrm{g}$ VS, illustrating the decrease in lag phase with an increase in the quantity of biochar added.

Comparing the LC and HC of zeolite showed no significant difference ( $p$-value $=1.000)$ after 48 days of digestion. The ZEO-LC and ZEO-HC at Day 15 produced $8.1 \%$ and $4.7 \%$ more $\mathrm{CH}_{4}$ than B-Char-LC and HC, respectively. Yet, by 48 days, there were no significant differences between LC and HC of B-Char and ZEO ( $p$-values $=0.974$ and 1.000, respectively). The observed lag in digestion in the mixtures containing CW alone or low concentrations of zeolite or biochar could be as a result of the rapid acidification of $\mathrm{CW}$ and inadequate buffer to provide the necessary buffer for microbial community and methanogens, and thus, a longer lag phase for microbial recovery.

The combined effects of manure and biochar showed that CW + PL + B-Char produced significantly more $\mathrm{CH}_{4}$ at Days 15 and 20 (273 and $400 \mathrm{~mL} \mathrm{CH}_{4} / \mathrm{g} \mathrm{VS}$, respectively; $p$-values < 0.001) than $\mathrm{CW}+$ B-Char (39.9 and $265 \mathrm{~mL} \mathrm{CH}_{4} / \mathrm{g}$ VS, respectively). After Day 20, the daily $\mathrm{CH}_{4}$ production of $\mathrm{CW}+\mathrm{PL}$ + B-Char decreased, while CW + B-Char increased and resulted in higher cumulative $\mathrm{CH}_{4}$ over 44 days. While the addition of $\mathrm{PL}$ or DM to $\mathrm{CW}$ increased $\mathrm{CH}_{4}$ production in the first 15 days of digestion, the $\mathrm{CW}+\mathrm{PL}+\mathrm{B}-\mathrm{Char}-\mathrm{HC}$ treatment yielded $400 \mathrm{~mL} \mathrm{CH}_{4} / \mathrm{g}$ VS $\left(84.8 \%\right.$ of total cumulative $\left.\mathrm{CH}_{4}\right)$ in the first 15 days, with this reduction is lag phase likely attributed to the combined presence of biochar and poultry litter.

The ability of biochar to catalyze digestion by providing surface area for the colonization of the microbial cell was previously reported in a review by Mumme et al. [21]. The CW substrate used in our experiment contained a low $\mathrm{pH}$ and when co-digested with biochar and manure showed an improved $\mathrm{AD}$ process due to the buffer provided by manure and biochar [20], as observed in the first two weeks of our experiment.

\subsection{Volatile Solids and COD Reduction during Digestion}

Chemical oxygen demand (COD) and VS reduction is associated with $\mathrm{CH}_{4}$ production. The substrate mixture containing CW + ZEO-HC showed the highest VS and COD reductions during digestion ( $66 \%$ and $49 \%$ ), which corresponded with the highest cumulative $\mathrm{CH}_{4}$ production (Table 2). Similar trends were reported in previous work [18,29]. Jiraprasertwong et al. used cassava wastewater in a three-stage up flow anaerobic sludge blanket (UASB) reactor and showed a steady reduction in COD removal with increasing COD loading and an increasing biogas production up to 15 $\mathrm{kg} \mathrm{COD} / \mathrm{m}^{3} \mathrm{~d}$ (one reactor) and $10 \mathrm{~kg} / \mathrm{m}^{3} \mathrm{~d}$ (two reactors) [18]. For comparison, our batch study had a one-time COD loading for each substrate tested that ranged from 25 to $43 \mathrm{~kg} \mathrm{COD} / \mathrm{m}^{3}$, respectively. 


\subsection{Scale-Up Model}

A medium size cassava factory in Nigeria processes $3000-6000 \mathrm{~kg}$ of cassava tubers per day, yielding 1000-2000 L CW/d. The size of the digester needed to co-digest CW with PL was calculated to be $50 \mathrm{~m}^{3}\left(40 \mathrm{~m}^{3}\right.$ liquid and $10 \mathrm{~m}^{3}$ biogas headspace), as shown in Figure 3 . The quantity of PL added to digester would vary from $56 \mathrm{~kg} / \mathrm{d}$ during high cassava production (March to October) to $28 \mathrm{~kg} / \mathrm{d}$ during low cassava production (November to February) to maintain a 1:1 ratio (by VS). The hydraulic retention time (HRT) would vary from 20 days during high cassava production to 40 days during low cassava production, which should result in $78.8 \%$ to $96.5 \%$ of the cumulative $\mathrm{CH}_{4}$ production from the 48-day BMP test (Table 4). Using the results from CW:PL (1:1), the daily $\mathrm{CH}_{4}$ production in the $50 \mathrm{~m}^{3}$ digester would be $28.9 \mathrm{~m}^{3} \mathrm{CH}_{4} / \mathrm{d}$ (20-day HRT) to $19.2 \mathrm{~m}^{3} \mathrm{CH}_{4} / \mathrm{d}$ (40-day HRT), with an annual $\mathrm{CH}_{4}$ production of $9403 \mathrm{~m}^{3} \mathrm{CH}_{4} / \mathrm{yr}$. Using Gibbs free energy $\left(\Delta \mathrm{G}_{\mathrm{CH} 4}=890.4 \mathrm{~kJ} / \mathrm{mol}\right)$ [41], the annual $\mathrm{CH}_{4}$ production would be equivalent to $373,327 \mathrm{MJ} / \mathrm{yr}$ and 24.9 tons of firewood/yr saved, based on $15 \mathrm{MJ} / \mathrm{kg}$ of firewood used for heating [42].

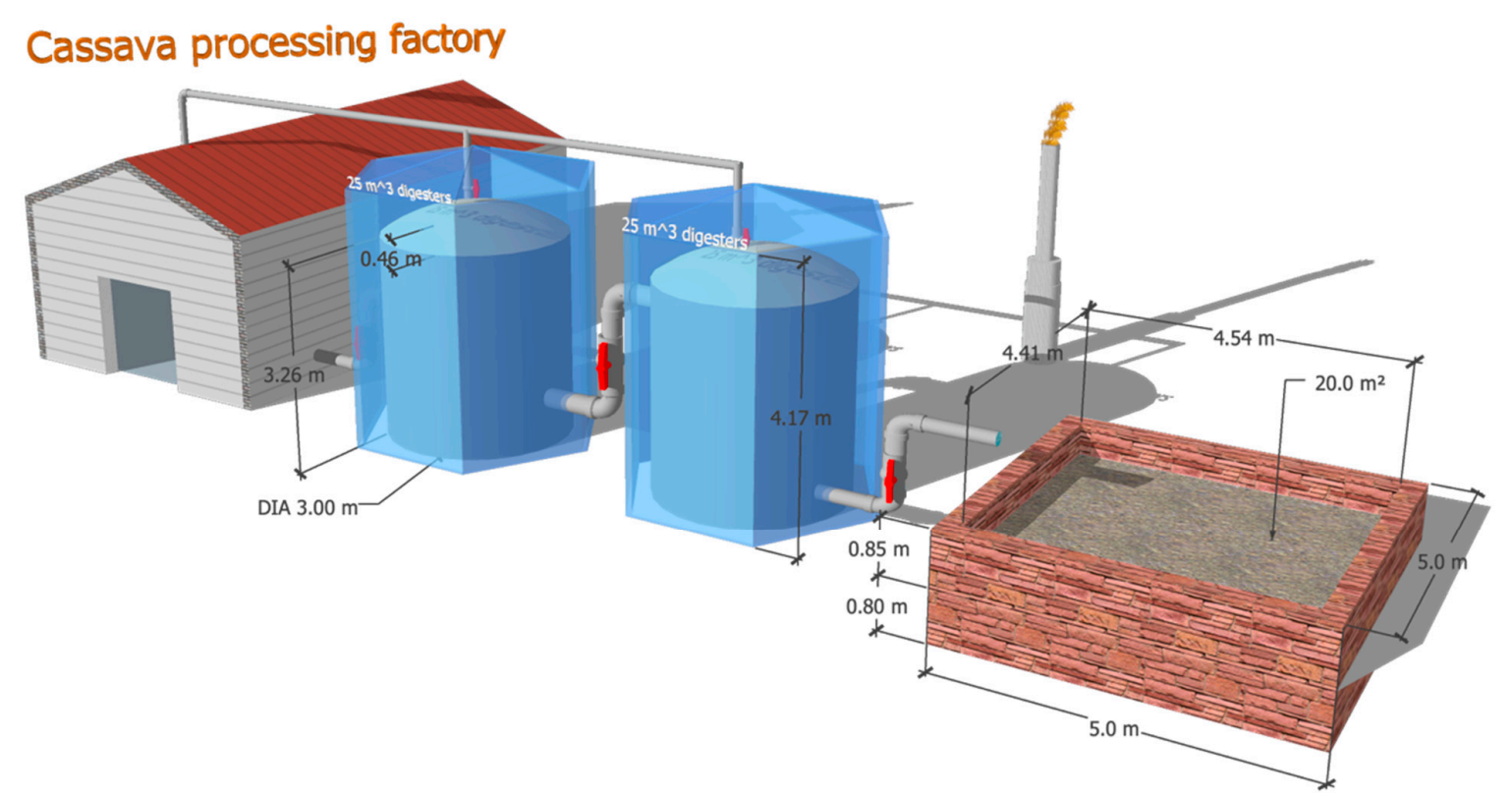

Figure 3. Scale-up model for a cassava processing factory, with two $25 \mathrm{~m}^{3}$ digesters plumbed in series to treat cassava wastewater and poultry manure with the utilization of the digestate for fertilizer.

The estimated cost of the digester system, including two flexible PVC bag digesters, greenhouse enclosures, plumbing, and gas piping, was estimated to be $\$ 7500\left(\$ 150 / \mathrm{m}^{3}\right.$ digester) (Shenzhen Puxin Technology Co. Ltd., Shenzhen, China). This cost does not take into consideration the land value or the cost of a heating system. A heating system would likely not be necessary in Nigeria, with average maximum and minimum ambient temperatures of 33 and $25^{\circ} \mathrm{C}$ respectively [43], which are within the mesophilic temperature range. While biogas production decreases with temperature, this decrease is more pronounced below the mesophilic range $\left(<25^{\circ} \mathrm{C}\right)$ [30]. The digester design also includes a greenhouse covering the digester, which our previous research has shown can significantly increase $\left(6.8-24.5^{\circ} \mathrm{C}\right)$ the digester temperature and help maintain a more consistent digestion temperature throughout the day [44]. Assuming a 10-year lifetime and $8 \%$ discount rate, the discounted capital investment would be $\$ 8617$. Based on the expected annual $\mathrm{CH}_{4}$ production, the cost would be $\$ 0.09 / \mathrm{m}^{3}$ $\mathrm{CH}_{4}$, which does not take into account the value of the produced fertilizer from the digester effluent. Assuming a natural gas price of $\$ 0.6 / \mathrm{m}^{3}$ ( $\$ 1.2 / \mathrm{kg}$ natural gas) [45], the system would have a yearly profit of $\$ 5642 / y r$. The net present value (NPV) is calculated as $\$ 47,805$, which does not take into consideration the value of the digestate, which can provide valuable nutrients to produce cassava and/or other crops. The price of adding zeolite or biochar was not included, since these additives 
may not be available and did not increase the overall biogas production, only decreased the lag phase associated with biogas production. If a higher throughput is desired or if the $\mathrm{pH}$ is not stabilized, the addition zeolite or biochar could be added to the full-scale system, if available.

\section{Conclusions}

Anaerobic digestion of cassava wastewater was shown to be viable, with $\mathrm{CH}_{4}$ production enhanced by additions of zeolite and biochar. Co-digestion with dairy and poultry manure decreased the lag phase of digestion but did not increase overall $\mathrm{CH}_{4}$ production, likely due to the more recalcitrant materials within the manure feedstock compared to $\mathrm{CW}$. While $\mathrm{CH}_{4}$ production was more efficient with $\mathrm{CW}$-only (higher $\mathrm{CH}_{4} / \mathrm{g}$ VS included), more gross energy production $\left(\mathrm{CH}_{4} / \mathrm{g}\right.$ substrate added) occurred with the manure substrates due to the higher VS content of these substrates compared to the relatively dilute $\mathrm{CW}$. Poultry litter generally contributed to higher $\mathrm{CH}_{4}$ production when digested with CW compared to the use of DM, likely due to the higher N content of the PL raising the low C:N value of CW. All combinations of DM and PL showed that adding $\mathrm{CW}$ increased their overall $\mathrm{CH}_{4}$ potential compared to the mono-digestion of PL or DM-only.

Co-digesting CW with PL with or without biochar in a typical rural cassava processing industry can significantly enhance the valorization of $\mathrm{CW}$ by yielding more $\mathrm{CH}_{4}$ in less time and an estimated profit of $>\$ 5000 / y$, with the creation of valuable fertilizer. The reduction in COD achieved through the digestion of $\mathrm{CW}$ could contribute significantly to reducing pollution of surface water due to indiscriminate disposal of untreated $\mathrm{CW}$, as currently practiced in many rural settings. The potential application of digestate for land treatment should be further explored as a means of adding value to the overall cassava processing and value chain.

Author Contributions: Conceptualization, C.G.A., A.H., and S.L.; Data curation, C.G.A.; Formal analysis, C.G.A. and A.H.; Funding acquisition, C.G.A. and S.L.; Investigation, C.G.A.; Methodology, C.G.A., A.H., and S.L.; Project administration, S.L.; Resources, S.L.; Software, C.G.A. and A.H.; Supervision, S.L. and A.H.; Validation, C.G.A. and A.H.; Visualization, C.G.A., A.H., and S.L.; Writing-original draft, C.G.A.; Writing-review and editing, C.G.A., A.H., and S.L. All authors have read and agreed to the published version of the manuscript.

Funding: This research was funded by the US Department of State Fulbright Foreign Student Program, administered by International Institute for Education (IIE) and conducted at the Department of Environmental Science and Technology (ENST) at the University of Maryland, College Park, USA.

Acknowledgments: Special thanks to all the graduate students, especially Abhinav Choudhury, and to the undergraduate students who helped during sample preparation.

Conflicts of Interest: The authors declare no conflict of interest.

\section{References}

1. Glanpracha, N.; Annachhatre, A.P. Anaerobic co-digestion of cyanide containing cassava pulp with pig manure. Bioresour. Technol. 2016, 214, 112-121. [CrossRef] [PubMed]

2. Panichnumsin, P.; Nopharatana, A.; Ahring, B.; Chaiprasert, P. Production of methane by co-digestion of cassava pulp with various concentrations of pig manure. Biomass Bioenergy 2010, 34, 1117-1124. [CrossRef]

3. Sun, L.; Wan, S.; Yu, Z.; Wang, Y.; Wang, S. Anaerobic biological treatment of high strength cassava starch wastewater in a new type up-flow multistage anaerobic reactor. Bioresour. Technol. 2012, 104, $280-288$. [CrossRef] [PubMed]

4. FAOStat 2017. Available online: http://www.fao.org/faostat/en/\#data/QC/visualize (accessed on 4 November 2019).

5. Achi, C.G.; Coker, A.O.; Sridhar, M.K.C. Utilization and Management of Bioresources. Proceedings of 6th IconSWM; Kumar Ghosh, S., Ed.; Springer: Singapore, 2018; pp. 77-90.

6. Araujo, I.R.C.; Gomes, S.D.; Tonello, T.U.; Lucas, S.D.; Mari, A.G.; Vargas, R.J. Methane Production from Cassava Starch Wastewater in Packed-Bed Reactor and Continuous Flow. Eng. Agric. 2018, 38, $270-276$. [CrossRef] 
7. FAO; IFAD. A review of cassava in Africa with country case studies on Nigeria, Chana, the United Republic of Tanzania, Uganda and Benin. In Processing of the Validation Forum on the Global Cassava Development Strategy; The Food and Agricultural Organization of the United Nations: Rome, Italy; International Fund for Agricultural Development: Rome, Italy, 2005; Volume 2, Available online: http://www.fao.org/3/a-a0154e.pdf (accessed on 4 November 2019).

8. Zhang, M.; Xie, L.; Yin, Z.; Khanal, S.K.; Zhou, Q. Biorefinery approach for cassava-based industrial wastes: Current status and opportunities. Bioresour. Technol. 2016, 215, 50-62. [CrossRef] [PubMed]

9. Kaewkannetra, P.; Imai, T.; Garcia-Garcia, F.J.; Chiu, T.Y. Cyanide removal from cassava mill wastewater using Azotobactor vinelandii TISTR 1094 with mixed microorganisms in activated sludge treatment system. J. Hazard. Mater. 2009, 172, 224-228. [CrossRef] [PubMed]

10. Hassanein, A.; Lansing, S.; Tikekar, R. Impact of metal nanoparticles on biogas production from poultry litter. Bioresour. Technol. 2019, 275, 200-206. [CrossRef]

11. Paulo, P.L.; Colman-Novaes, T.A.; Obregao, L.D.S.; Boncz, M.A. Anaerobic Digestion of Cassava Wastewater Pre-treated by Fungi. Appl. Biochem. Biotechnol. 2013, 169, 2457-2466. [CrossRef] [PubMed]

12. Ubalua, A.O. Cassava wastes: Treatment options and value addition alternatives. Afr. J. Biotechnol. 2007, 6, 2065-2073.

13. Palma, D.; Fuess, L.T.; de Lima-Model, A.N.; da Conceicao, K.Z.; Cereda, M.P.; Tavares, M.H.F.; Gomes, S.D. Using dolomitic limestone to replace conventional alkalinization in the biodigestion of rapid acidification cassava processing wastewater. J. Clean. Prod. 2018, 172, 2942-2953. [CrossRef]

14. Amorim, M.C.C.; de S. e Silva, P.T.; Gavazza, S.; Sobrinho, M.A. Viability of rapid startup and operation of UASB reactors for the treatment of cassava wastewater in the semi-arid region of northeastern Brazil. Can. J. Chem. Eng. 2018, 96, 1036-1044. [CrossRef]

15. Glanpracha, N.; Basnayake, B.M.N.; Rene, E.R.; Lens, P.N.L.; Annachhatre, A.P. Cyanide degradation kinetics during anaerobic co-digestion of cassava pulp with pig manure. Water Sci. Technol. 2018, 77, 650-660. [CrossRef] [PubMed]

16. Carbone, S.R.; da Silva, F.M.; Tavares, C.R.; Dias Filho, B.P. Bacterial population of a two-phase anaerobic digestion process treating effluent of cassava starch factory. Environ. Technol. 2002, 23, 591-597. [CrossRef] [PubMed]

17. Jiang, H.; Qin, Y.; Gadow, S.I.; Ohnishi, A.; Fujimoto, N.; Li, Y.Y. Bio-hythane production from cassava residue by two-stage fermentative process with recirculation. Bioresour. Technol. 2018, 247, 769-775. [CrossRef] [PubMed]

18. Jiraprasertwong, A.; Maitriwon, K.; Chavadej, S. Production of biogas from cassava wastewater using a three-stage upflow anaerobic sludge blanket (UASB) reactor. Renew. Energy 2019, 130, 191-205. [CrossRef]

19. Rajagopal, R.; Saady, N.M.C.; Torrijos, M.; Thanikal, J.V.; Hung, Y. Sustainable Agro-Food Industrial Wastewater Treatment Using High Rate Anaerobic Process. Water 2013, 5, 292-311. [CrossRef]

20. Fagbohungbe, M.O.; Herbert, B.M.J.; Hurst, L.; Ibeto, C.N.; Li, H.; Umani, S.Q.; Semple, K.T. The challenges of anaerobic digestion and the role of biochar in optimizing anaerobic digestion. Waste Manag. 2017, 61, 236-249. [CrossRef]

21. Mumme, J.; Srocke, F.; Heeg, K.; Werner, M. Use of biochars in anaerobic digestion. Bioresour. Technol. 2014, 164, 189-197. [CrossRef]

22. Montalvo, S.; Guerrero, L.; Borja, R.; Sanchez, E.; Milan, Z.; Cortes, I.; Rubia, M.A. Application of natural zeolites in anaerobic digestion processes: A review. Appl. Clay Sci. 2012, 58, 125-133. [CrossRef]

23. Montalvo, S.; Diaz, F.; Guerrero, L.; Sanchez, E.; Borja, R. Effect of particle size and doses of zeolite addition on anaerobic digestion processes of synthetic and piggery wastes. Process Biochem. 2005, 40, 1475-1481. [CrossRef]

24. Lin, R.; Cheng, J.; Yang, Z.; Ding, L.; Zhang, J.; Zhou, J.; Cen, K. Enhanced energy recovery from cassava ethanol wastewater through sequential dark hydrogen, photo hydrogen and methane fermentation combined with ammonium removal. Bioresour. Technol. 2016, 214, 686-691. [CrossRef] [PubMed]

25. Roopnarain, A.; Adeleke, R. Current status, hurdles and future prospects of biogas digestion technology in Africa. Renew. Sustain. Energy Rev. 2017, 67, 1162-1179. [CrossRef]

26. Moody, L.B.; Burns, R.T.; Bishop, G.; Sell, S.T.; Spajic, R. Using biochemical methane potential assays to aid in co-substrate selection for co-digestion. Appl. Eng. Agric. 2011, 27, 433-439. [CrossRef] 
27. American Public Health Association (APHA); American Water Works Association (AWWA); Water Environment Federation (WEF). Standard Methods for the Examination of Water and Wastewater, 21st ed.; APHA-AWWA-WEF: Washington, DC, USA, 2005.

28. Adams, R.C.; MacLean, F.S.; Dixon, J.K.; Bennett, F.M.; Martin, G.I.; Lough, R.C. The Utilization of Organic Wastes in N.Z.: Second Interim Report of the Inter-Departmental Committee. 1951. Available online: http://compost.css.cornell.edu/calc/carbon.html (accessed on 28 November 2019).

29. Peres, S.; Monteiro, M.R.; Ferreira, M.L.; do Nascimento, A.F., Jr.; Palha, A.P. Anaerobic Digestion Process for the Production of Biogas from Cassava and Sewage Treatment Plant Sludge in Brazil. BioEnergy Res. 2018, 12, 150-157. [CrossRef]

30. Witarsa, F.; Lansing, S. Quantifying methane production from psychrophilic anaerobic digestion of separated and unseparated dairy manure. Ecol. Eng. 2015, 78, 95-100. [CrossRef]

31. Lin, R.; Cheng, J.; Murphy, J.D. Unexpectedly low biohydrogen yields in co-fermentation of acid pretreated cassava residue and swine manure. Energy Convers. Manag. 2017, 151, 553-561. [CrossRef]

32. Hagos, K.; Zong, J.; Li, D.; Liu, C.; Lu, X. Anaerobic co-digestion process for biogas production: Progress, challenges and perspectives. Renew. Sustain. Energy Rev. 2017, 76, 1485-1496. [CrossRef]

33. Calabrò, P.S.; Fazzino, F.; Folino, A.; Paone, E.; Komilis, D. Semi-Continuous Anaerobic Digestion of Orange Peel Waste: Effect of Activated Carbon Addition and Alkaline Pretreatment on the Process. Sustainability 2019, 11, 3386. [CrossRef]

34. Calabrò, P.S.; Fazzino, F.; Folino, A.; Scibetta, S.; Sidari, R. Improvement of semi-continuous anaerobic digestion of pre-treated orange peel waste by the combined use of zero valent iron and granular activated carbon. Biomass Bioenergy 2019, 129. [CrossRef]

35. Abouelenien, F.; Namba, Y.; Kosseva, M.R.; Nishio, N.; Nakashimeda, Y. Enhancement of methane production from co-digestion of chicken manure with agricultural wastes. Bioresour. Technol. 2014, 159, 80-87. [CrossRef]

36. Abouelenien, F.; Namba, Y.; Nishio, N.; Nakashimeda, Y. Dry Co-Digestion of Poultry Manure with Agriculture Wastes. Appl. Biochem. Biotechnol. 2016, 178, 932-946. [CrossRef] [PubMed]

37. Riaño, B.; Molinuevo, B.; García-González, M.C. Potential for methane production from anaerobic co-digestion of swine manure with winery wastewater. Bioresour. Technol. 2011, 102, 4131-4136. [CrossRef] [PubMed]

38. Milan, Z.; Sanchez, E.; Weiland, P.; Borja, R.; Martõn, A.; Ilangovan, K. Infuence of different natural zeolite concentrations on the anaerobic digestion of piggery waste. Bioresour. Technol. 2001, 80, 37-43. [CrossRef]

39. Fagbohungbe, M.O.; Herbert, B.M.; Hurst, L.; Li, H.; Usmani, S.Q.; Semple, K.T. Impact of biochar on the anaerobic digestion of citrus peel waste. Bioresour. Technol. 2016, 216, 142-149. [CrossRef] [PubMed]

40. Jang, H.M.; Choi, Y.K.; Kan, E. Effects of dairy manure-derived biochar on psychrophilic, mesophilic and thermophilic anaerobic digestions of dairy manure. Bioresour. Technol. 2018, 250, 927-931. [CrossRef] [PubMed]

41. Hassanein, A.; Witarsa, F.; Guo, X.; Yong, L.; Lansing, S. Next generation digestion: Complementing anaerobic digestion (AD) with a novel microbial electrolysis cell (MEC) design. Int. J. Hydrogen Energy 2017, 42, 28681-28689. [CrossRef]

42. FAO 1998, Woodfuel Flow Study of Phnom Penh, Cambodia. 1998. Available online: http://www.fao.org/3/ x5667e/x5667e04.htm (accessed on 28 November 2019).

43. World Weather online. Ibadan Monthly Climate Averages. 2019 November 2019. Available online: https: //www.worldweatheronline.com/ibadan-weather-averages/oyo/ng.aspx (accessed on 28 November 2019).

44. Hassanein, A.; Qiu, L.; Junting, P.; Yihong, G.; Witarsa, F.; Hassanain, A. Simulation and validation of a model for heating underground biogas digesters by solar energy. Ecol. Eng. 2015, 82, 336-344. [CrossRef]

45. Asikhia, O.; Orugbo, D. Marketing Cost Efficiency of Natural Gas in Nigeria. Pet.-Gas Univ. Ploiesti Bull. 2011, LXIII, 1-13.

(C) 2020 by the authors. Licensee MDPI, Basel, Switzerland. This article is an open access article distributed under the terms and conditions of the Creative Commons Attribution (CC BY) license (http://creativecommons.org/licenses/by/4.0/). 